\title{
THE INTELLECTUAL AND CULTURAL SCENE IN THE DUAL MONARCHY
}

\author{
MIHÁLY SZEGEDY-MASZÁK \\ Eötvös Loránd University, Budapest \\ Hungary
}

\begin{abstract}
"Erschütternd ist der Untergang des Geschlechts." ("Shocking is the decline of mankind." Georg Trakl: Helian)

The intellectual and artistic culture of the Dual Monarchy was marked by a diversity and richness that was inseparable from the multi-ethnic and multilingual nature of the Habsburg territories. As attempts to integrate the variety of cultural products of the Monarchy into a coherent identity run the risk of oversimplification, the following article offers a discussion of the works of several individual authors, artists, composers, philosophers, and scientists, locating these works within often divergent intellectual and artistic trends the broad range of which may be the single most conspicuous feature of the cultural identity of the Habsburg Empire. It presents the legacy of the Dual Monarchy as one rich in diverse contributions to the cultures of Europe and the world.
\end{abstract}

Keywords: Austria, Austria-Hungary, Austro-Hungary, Dual Monarchy, Habsburg, multilingual, literature, visual arts, music, philosophy, psychoanalyses, Zionism, cultural history

\section{The Identity of Austrian Culture}

"I think the good Austrian (Grillparzer, Lenau, Bruckner, Labor) is particularly hard to understand. In a sense subtler than anything else, and its truth never leans towards plausibility (ist nie auf Seiten der Wahrscheinlichkeit)" (Wittgenstein 1981, 3). On the face of it, this remark made by Ludwig Wittgenstein (18891951) in 1929 is about Austria. In fact, the list of names suggests that the philosopher evoked memories of the cultural legacy of the entire Habsburg Monarchy. Niebsch von Strehlenau, known in German literature as Nikolaus Lenau (1802-1850), the grandson of a member of the German bourgeoisie of Pest, was born in the Southern region of the historical kingdom of Hungary and exerted a strong influence on Sándor Petöfi (1823-1849), especially with his poems presenting the plain land of the Carpathian basin. One of Schönberg's teachers, Josef 
Labor (1842-1914), the blind composer, organist, and pianist brought to the Wittgenstein home by the philosopher's mother Leopoldine (née Kalmus), was a Czech musician. If one remembers that Ein treuer Diener seines Herrn (A Faithful Servant of his Master, 1830), one of the outstanding works by the Viennese playwright Franz Grillparzer (1791-1872), is about well-known incidents of Hungarian history and the tension between Hungarians and their Western neighbours, the conclusion is inescapable that Wittgenstein's statement is about the cultural identity of the multi-ethnic and multilingual Habsburg Empire.

The philosopher's list of names refers to literature and music. Although there have been attempts to find the features specific to Austrian culture in the sphere of ideas, it is doubtful whether one can speak of a specific Austrian school of philosophy on the basis of a complex of criteria consisting of empiricism, "Sprachkritik" (critique of language), the rejection of Kantianism, and strong reservations about irrational approaches to existence (Neumer 2004, 103, 125). Since my field is not philosophy, it cannot be my task to dispute the arguments for or against the existence of a way of thinking specific to the Dual Monarchy. All I can say is that the multilingual nature of this region may be responsible for the rise of theoretical speculations about language, starting with Fritz Mauthner (1849-1923), an apostate Jew born in Bohemia who wrote novels, short stories, and plays and published several works on language, among them a three-volume Beiträge zu einer Kritik der Sprache (Contributions to a Critique of Language, 1901-1902) and Die Sprache (Language, 1907). Relying on "Völkerpsychologie" (the psychology of peoples), he took issue with the ideal of a common pattern underlying all languages and developed a cultural relativism.

There is no reason to believe that Dezsö Kosztolányi (1885-1936), poet, novelist, short-story writer, essayist, and translator, was familiar with Mauthner's works. Born in Szabadka (today Subotica, in Voivodina), this Hungarian writer was brought up in a region in which Hungarian, German, Serbian, and possibly even other languages (Slovak and Romanian) were spoken. His language-based cultural relativism resembled not only Mauthner's ideas but also those of Karl Popper (1902-1994), born and educated in Vienna. Popper's argument that "a precise translation of a difficult text simply does not exist", his claim that "if the two languages have a different structure, some theories may be almost untranslatable (as Benjamin Lee Whorf has shown so beautifully)" (Popper 1982, 24) are strikingly similar to Kosztolänyi's thesis that "translation is always distortion", either on the level of the signified or on that of the signifier (Kosztolányi 2002, 511-512).

In view of the multilingual nature of the Habsburg Empire, it is understandable that translation was a widely discussed issue. Since German served as the medium of communication, any approach to the culture of the region has to consider the difference between German and other languages. The translation of the culture of 
the Dual Monarchy is partly a linguistic operation. Some of the key terms of the Tractatus Logico-Philosophicus, the first major work by the Viennese philosopher Ludwig Wittgenstein, published in 1921 but written earlier - such as "Bild" and its associated form "abbildenden internen Bezichung", "stellen dar", or "stellen vor" - go back to earlier thinkers and are virtually untranslatable. In a French philosopher's version the relevant expression is "cette relation interne de représentation" (Granger 1969, 106), whereas in C. K. Ogden's English rendering the same words appear as "pictorial internal relation". Both could be called misleading. Leo Black, the translator of the essays of the Austrian composer Arnold Schönberg (1874-1951), had serious difficulties in trying to find English equivalents for not only "Darstellung" but also "Anschauung". I would even raise doubts about the same translator's thesis that "Ideas' for Gedanken is easy enough" (Schoenberg 1984, 18). The equivalents of "Setzkunst" and "Satzkunst": "the craft of scoring" and "the craft of composing" (Schoenberg 1984, 323) are no less unsatisfactory. Such examples may explain why in his later years Schönberg preferred to write in English rather than ask for a translation. Other examples could also confirm that the multilingual situation in his homeland may have led Wittgenstein to the thesis he formulated in his later years: "Every sign by itself (allein) seems dead. What gives it life? - In use it is alive (lebt es)" (Wittgenstein 1974, 128).

Of course, the difficulties in interpreting the culture of the Monarchy cannot be reduced to linguistic matters. "One should never forget that what one learns in school about history is the truth only insofar as it does not interfere with the political, philosophical, moral or other beliefs of those in whose interest the facts are told, coloured or arranged" (Schoenberg 1984, 239). Schönberg made this warning in a lecture delivered in the United States, at a time he became exposed to different views on the Habsburg state abolished after World War I. Undoubtedly, even those educated in the Dual Monarchy differed in their retrospective evaluations. Chapter 19 in Book I of the Klagenfurt-born Robert Musil's (1880-1942) Der Mann ohne Eigenschaften (Man without Qualities), first published in 1930, contains a letter in which Ulrich's father outlines plans to devote "the whole year 1918 to the jubilee of our peace emperor" (Musil 1970, 79). This irony is supported by one of the standard works on the Austria of the early twentieth century. According to its authors, Wittgenstein "never overcame the crisis provoked by the collapse, in 1918, of the seemingly eternal framework of worldly falsehood into which he had grown up" (Janik and Toulmin 1973, 242). It is worth noting that the value judgment comes from the American authors of the book and not from the Austrian philosopher.

In sharp contrast to Musil's interpretation of the Monarchy as a state so ethnically heterogeneous that it was doomed to fall apart, in Sándor Márai's (19001989) A gyertyák csonkig égnek (1942, translated as Embers) it is presented as a 
highly structured way of life, a mode of existence in which each participant had his or her proper place. The contrast is even sharper if one remembers that Márai belonged to the Hungarian community that was strongly influenced by the memory of the 1848-49 revolution crushed by the Romanovs and the Habsburgs. In 1852 a statue was erected in the fortress of Buda in memory of Heinrich Hentzi, the Austrian general who died in May 1849 when the Hungarian revolutionary army recaptured the fortress from the Austrians. Many Hungarians viewed this monument as a symbol of the humiliation of their people. In Kosztolányi's short novel Pacsirta (Skylark, 1924) the reader is reminded of this. Márai, of a later generation, refrained from any allusion to $1848-49$. By 1942 many Hungarians became convinced that for their community conditions in the Dual Monarchy were favourable to those of the period between the two world wars. The fact that since the 1990s Embers has become popular in Italian, German, and English translation is inseparable from the current nostalgia for the Dual Monarchy. Márai's interpretation closely resembles that of Stefan Zweig (1881-1942). His idealized description of Vienna as a system of concentric circles also dates from the time of World War II:

\begin{abstract}
Die kaiserliche Burg war das Zetrum nicht nur im räumlichen Sinn, sondern auch im kulturellen der Übernationalität der Monarchie. Um diese Burg bildeten die Palais des österreichischen, polnischen, tschechischen, ungarischen Hochadels gewissemaßen den zweiten Wall. Dann kam die 'gute Gesellschaft', bestehend aus dem kleineren Adel, der hohen Beamtenschaft, der Industrie und den 'alten Familien', darunter dann das Kleinbürgertum und das Proletatiat.

(The imperial castle was the centre of the supranationality of the Monarchy, not only in a spatial but also in a cultural sense. Around this castle the palaces of the Austrian, Polish, Czech, and Hungarian aristocrats formed a kind of second wall. Then came the 'good society', consisting of the lesser nobility, the high-raking civil servants, the industrialists, the 'old families', and finally the lower bourgeoisie and the workers. Zweig 1981, 31-32).
\end{abstract}

These words came from a man of culture for whom the Dual Monarchy "war das goldene Zeitalter der Sicherheit" ("meant the golden days of certainty", Zweig 1981, 25). As a Jew of Moravian origin, he felt at home in Vienna. In his view the Habsburg Empire had been destroyed by the Great Powers. It represented a tolerant world that always welcomed the new settlers. Its disappearance meant a qualitative loss for human culture. Shortly after he had written about this loss, Zweig committed suicide with his wife in Brazil, a country in which he remained an outsider.

Some of the Western interpretations of the culture of the Dual Monarchy were based on more or less explicitly Marxist preconceptions, on the idea that culture 
was the product of politics. Carl E. Schorske's assumption that "the growth of a new higher culture seemed to take place in Austria as in a hothouse, with political crisis providing the heat" (Schorske 1980, xxvii) is a telling example. The abundance of the cultural products of the Monarchy obstructs their systematic presentation in a short chapter; therefore, a somewhat arbitrary procedure must be used here. I am under no illusion that what follows is any more than a summary that gives no justice to all the important fields of cultural activity. With a certain self-irony, I could quote the great poet Rainer Maria Rilke (1875-1926), who maintained "daß man nicht das Recht hatte, ein Buch aufzuschlagen, wenn man sich nicht verpflichtete, alle zu lesen" ("that one has no right to open a book unless one obliges oneself to read all books", Rilke 1997, 167).

In 1958 the outstanding musician Pierre Boulez gave a list of the five greatest composers of the twentieth century. The fact that four of them (Schönberg, Bartók, Webern, and Berg) were born and developed their style in the Dual Monarchy (Boulez 1966, 34) is a testimony to the eminence of the musical culture of the Austro-Hungarian Empire. In 1970 the Viennese Secession Exhibition at the Royal Academy in London drew attention to the international significance of Viennese Art Nouveau. The literature of the Dual Monarchy is widely read all over the world.

No less spectacular were the achievements in science. One example is the contribution of Ernst Mach (1838-1916). Born in Brünn (today Brno), this experimental physicist taught in Graz and Prague before being invited to the University of Vienna in 1895. His criticism of Newton's theory of absolute space and time and his philosophy of science, his Die Mechanik in ihrer Entwicklung (1883, translated as The Science of Mechanics), Die Analyse der Empfindungen (Analysis of Sensations, 1883), and Erkenntnis und Irrtum (Perception and Error, 1905) had a far-reaching influence. Robert Musil wrote his doctoral dissertation on his works (Beitrag zur Beurteilung der Lehren Machs, 1908) and Hugo von Hofmannstahl (1874-1929) attended his lectures. "Few great men have had an intellectual impact upon the twentieth century comparable to that of Ernst Mach", wrote Karl Popper (1902-1994) in his autobiography.

He influenced physics, physiology, psychology, the philosophy of science, and pure (speculative) philosophy. He influenced Einstein, Bohr, Heisenberg, William James, Bertrand Russell - to mention but a few names (Popper 1982, 151-152).

Mach's research proved to be crucial for fields ranging from optics, acoustics, wave theory, and the theory of kinaesthetic impressions to historical investigations. His reduction of knowledge to sensation inspired Lenin to write his Materialism and Empirio-Criticism (1909), "a violent attack on the Russian adherents of this philosophy" (Kolakowski 1972, 151). Last but not least, Mach can also be re- 
garded as a precursor to the logical positivists of the "Wiener Kreis" ("Vienna Circle") of the 1920s. His opponent Ludwig Boltzmann (1844-1906) could also be named as one of the Austrian scientists of international fame who were many-sided in both research and teaching. Born in Duino (now in Italy), he was appointed to a chair of physics at Graz and then accepted a chair of mathematics at Vienna, in 1873. After three years he was back at Graz, this time as the chair of experimental physics. In 1900 he moved to Leipzig, but in 1902 he returned to his chair of theoretical physics and was given Mach's philosophy course to teach. His statistical mechanics lies at the basis of twentieth-century thermodynamics, and his notion of a space of theoretical possibilities was an important source of inspiration for Wittgeinstein's Tractatus Logico-Philosophicus. Other fields could also be mentioned in this context.

\begin{abstract}
America owes its pre-eminence, in the medical sciences of our time, in no small part, to the thousands of medical students who traveled to Vienna at a time when the standards of American medicine were scandalously low, in order to study with such luminaries as Hebra, Škoda, Krafft-Ebing and Billroth (Janik and Toulmin 1973, 35).
\end{abstract}

To add one more item, let us remember that most of the physicists who helped the United States in World War II were born and trained in Budapest.

After 1920 many viewed the Dual Monarchy as a multi-national state that had failed. By the early twenty-first century interpretations have shifted: seeing the difficulties faced by the European Union, more and more people tend to appreciate the Habsburg Monarchy as an attempt at supranational integration. Such a revaluation is also supported by the growing recognition of the intellectual achievements associated with the state established in 1867.

\title{
2. Nationalist Ideology and Culture
}

As is well-known, the life of the Monarchy was inseparable from nationalistic movements. On 18 February 1853 János Libényi, a young Hungarian apprentice, tried to assassinate Franz Joseph in Vienna. Between 1856 and 1879 a neo-Gothic church, the so-called Votivkirche designed by H. Ferstel, was built on the site of the incident. The 1867 "Ausgleich" ("Compromise") replaced the tension between Austrians and Hungarians with a delicate balance, but Czech nationalism not only continued but increased in the last third of the century. Its adherents tried to forget that Prague "was a German cathedral city long before Vienna" (Janik and Toulmin 973, 49), and later ignored that great masters of the German language had been born in the Czech capital. Rilke must have heard some Czech spoken around him, not only in his native Prague but also in the Militär-Oberrealschule in 
Mährisch-Weißkirchen (today Hranice), where he started his military education in 1890 , fours years before Musil became a cadet there. One of his early poems, written in the 1890s and entitled Volksweise (Folk Tune) refers to a Czech melody one cannot forget even when living far from the region. Characteristically, Czech is associated in the poem with the singing of a peasant child. The emphasis is on the distance between the speaker and the singer. From the 1890s on Rilke spent most of his time abroad and composed his greatest works there, including the Duineser Elegien (Duino Elegies, 1912-1922) and Die Sonette an Orpheus (Sonnets to Orpheus, 1922).

No less divided was the population and cultural life of the Moravian capital. On December $6^{\text {th }}, 1884$, a performance of J. J. Kollár's play Magelona was given to celebrate the opening of the first Czech theatre in Brünn. On October 1-2, 1905, clashes occurred between Germans and Moravians in this city and a twenty-year-old carpenter's apprentice was killed. The statement that the "new anti-liberal mass movements - Czech nationalism, Pan-Germanism, Christian Socialism, Social Democracy, and Zionism - rose from below to challenge the trusteeship of the educated middle class" (Schorske 1980, 118) needs to be modified. Kálmán Mikszáth (1847-1910), a writer who earned national renown with the collections Tót atyafiak (Slovak Kinsfolk, 1881) and $A$ jó palócok (The Good Palóc People, 1882), stories about the two main ethnic communities of his native Upper Hungary, shrewdly observed in his parliamentary sketches Club és folyosó (Club and Lobby, 1887) that the Slavs of the Monarchy "were rapidly moving towards Russia" (Mikszáth 1887, 186) under the influence of the Pan-Slav movement sponsored from St. Petersburg. Even the most popular Hungarian prose writer of the nineteenth century, Mór Jókai (1825-1904), became aware of the Great Power interests vested in the fate of the Slavic minorities of the Monarchy. As a young man he participated in the 1848 anti-Habsburg revolution, but later he came to approve of the 1867 Compromise. One of the reasons for this change in attitude was his growing awareness of the Russian desire to dissolve the Habsburg Empire. Committed as he was to optimism, in his novel $A$ jövö század regénye ( $A$ Novel about the Next Century, 1872) he wrote about a victory of a future Habsburg, backed by the Hungarians, over Russia.

The interrelations between politics and art are always of great complexity. Both the Pan-Slavism that undermined and the supranationalism that supported the integrity of the Dual Monarchy produced great art. Béla Bartók (1881-1945) collected not only Hungarian folk music but also that of other nations, including those living in Central Europe. Két román tánc for piano (Two Romanian Dances, 1909, 1910), published in Budapest, and Négy szlovák népdal for mixed chorus (Four Slovak Folksongs, 1916), published in Vienna, are just two among Bartók's numerous works inspired by the music of the neighbours of the Hungarians. In sharp contrast, Leoš Janáček (1854-1928) focused on Slavic culture. In this sense 
he was more consistent than his immediate predecessors, Bedřich Smetana (1824-1884), the composer of the comic opera Prodaná Nevěsta (The Bartered Bride, 1866) and the cycle of six symphonic poems Má Vlast (My Country, 1874-1879), and Antonín Dvořák (1841-1904), whose overpopular Symphony in E Minor (1893), composed and first performed in the United States, has tunes alluding to African American music. "Smetana's orientation was specifically Czech and thus appeared to Janáček to be endangering his Moravian regionalism and his pan-Slav ideals", as a Czech musician remarked (Vogel 1962, 15). Although there is some continuity between the works of Dvořák and Janáček, e. g., the mixing of major and parallel minor is characteristic of both, the older composer's opera Rusalka (first performed in Prague in 1901) shows a far more superficial interest in Slavic folk music than Jenüfa, Janáček's first major work in the same genre, performed in Brünn in 1904. In fact, Janáček's passion for old Slavic traditions dates from his early youth. In 1869 the millennium of St. Cyrill's death was commemorated at Velehrad in South-Eastern Moravia. As a chorister of the Queen's Monastery of Old Brünn, the young boy participated in the festivities in memory of the struggle over the ecclesiastical language of Bohemia and Moravia, a struggle for political influence between Germans and Slavs. In 1873 Janáček was elected choir-master of the craftsmen's choral society named after Svatopluk, the somewhat legendary head of 9th-century Magna Moravia. This association, founded in 1868, one year after the creation of the Austro-Hungarian Monarchy, had obvious political purposes. In 1896, the year devoted to the millennium of the Hungarian state in Budapest, Janáček visited Russia, and in 1903 he organized, in Moravia, the folklore section for the Pan-Slav Exhibition in the city of the tzar. "I wrote the Violin Sonata in 1914 at the beginning of the war when we were expecting the Russians in Moravia", he remembered in 1922, and insisted that the high piano tremolo over the chorale-like part of the last (Adagio) movement represented "the Russian armies entering Hungary" (Vogel 1962, 218). Janáček's love of Russian culture dominated his activity even in his later years: the three-part orchestral rhapsody Taras Bulba (completed in 1918) was inspired by a story by Gogol, one his most successful operas Katya Kabanova (1921) by a nineteenth-century play by Alexander Nikolaevich Ostrovsky, his First String Quartet (first performed in 1924) by L. N. Tolstoy's Kreutzer Sonata, and his last opera $Z$ Mrtvého domu (From the House of the Dead, completed in 1928) by Dostoevsky's Zapiski iz myortvogo doma. Another major composition, the Mša Glagolskja (Glagolitic Mass, composed in 1926), a setting of an Old Church Slavonic version of the Latin ordinary, a ninth-century text by Cyril used in church services on 7 July (the day dedicated to Saints Cyril and Methods), affirmed the unity of all Slavs in an age moving away from that ideal. This work clearly shows 
that Janáčck's desire to return to the spiritual roots of Slavdom was part of a Romantic legacy.

Ironically, Liberalism was of some help to the cause of Pan-Slavism. In May 1913, it was discovered that the deputy director of the "K. u. K." (Imperial-andRoyal) intelligence, colonel Alfred Redl, was in the pay of the tsar. The fact that a General Staff officer had become a Russian agent in order to finance his homosexual life suggested that the sexual tolerance that was part of the Liberalism that made the Monarchy the centre of psycho-analysis penetrated all segments of society. Redl started his homosexual relations in a Cadet School similar to the one Musil attended. The explicit treatment of homosexual relations in a work like Musil's short novel Die Verwirrungen des Zöglings Törleß (1906, translated as Young Törless) would have been as impossible in Edwardian Britain or in the United States as the presentation of the extra-marital affairs of officers in a play such as Reigen (1900, translated as Merry-go-round and La Ronde), a popular work also known in film versions by the practising doctor, playwright, novelist, and short-story writer Arthur Schnitzler (1862-1931).

The restricted-suffrage system kept some radical Pan-Slavic nationalists away from the polls but fuelled the anti-Liberal movements. Without much exaggeration, it could be argued that most of the leading writers of Slavic nationalism spent their formative years in Vienna or Budapest. The Ukrainian Ivan Franko (1856-1916), the author of Moisei (Moses, 1905), a long poem about a leader's service to his people, received his doctorate from Vienna but failed to obtain a position at the University of Lemberg (L'vov) because of his socialist-nationalist declarations. The Slovenian Ivan Cankar (1876-1918), whose collection of poetry Erotika (1899) was confiscated by the Bishop of Laibach (Ljubljana), also spent years in Vienna, and the Croatian Miroslav Krleža (1893-1981) was sent to the military academy in Budapest before he fought in Galicia, an experience reflected in his Hrvatski bog Mars (The Croatian God Mars, 1922), a two-volume collection of stories that ridicules the Austro-Hungarian army.

The Compromise between Franz Joseph and the Hungarians, whose revolution of 1848-49 almost undermined Habsburg rule, was based on the two largest linguistic communities of the region. Germans constituted 24 per cent of the population, Hungarians 20 per cent, and Czechs (the third largest group) 13 per cent. The fact that the eminent historian František Palacky (1798-1876) attended the Slavic Congress held in Moscow in 1867 indicated that even some of the most civilized Czech intellectuals sympathized with pan-Slavism. Around the turn of the century Vienna made significant concessions to Prague. From 1897 every civil servant working in Bohemia or Moravia had to be bilingual and from 1907 every male adult citizen living in these two provinces was given the right to vote. Such measures constituted a disadvantage to the largely German speaking bourgeoisie, including the majority of Jews. 
National identity was often a matter of personal decision rather than ethnic origin. Bedřich Janáček, one of the brothers of the great Moravian composer, married Hedwig Schmied at Aspang (near Vienna) a couple of months before the outbreak of World War I, "became a German himself and brought up his four children as Germans" (Vogel 1962, 275). Franz Herzog, born in the region that is called Voivodina today, became a very successful Hungarian author of narrative fiction and plays under the name Ferenc Herczeg (1863-1954). What is more, as a member of the Hungarian parliament he represented the interests of the Liberals of the Dual Monarchy.

From the beginning of the new century some Slavic nationalists turned not to Russia but to Britain and France for support. Arguing that the Monarchy was a satellite of Germany, they insisted that the break-up of the Habsburg Monarchy was needed to stop the German policy of "Drang nach Osten" ("drive towards the East"). Such was the substance of the propaganda launched by Eduard Beneš, who in 1916 published a work entitled Détruisez l'Autriche-Hongrie in Paris. While it is true that the empire of Franz Joseph was strongly affected by such trends as Liberalism, Christian clericalism, socialism, and nationalism, Stefan Zweig was probably right in pointing out that the primary cause of the fall of the Dual Monarchy was a decision of certain French and British politicians to abolish it. Louis Léger's Le Panslavisme et l'intérêt français (1917) proves that pan-Slavism was appreciated by some French publicists as an antidote to German nationalism. Freemasons, who played a major role in literary life, also asked for the elimination of the Habsburg Monarchy at their congress in Paris on June 28-30, 1917.

To avoid the generalization that all Slavs sought the downfall of the Dual Monarchy, it is worth remarking that Croats were divided. While some went to study at the University of Prague, where "they had been strongly influenced by T. G. Masaryk" (Krišto 2005, 76) and later organized such demonstrations as the burning of the Hungarian flag at the Ban Jelačić Square in Zagreb in 1895 or the rebellion that forced Ban Károly Khuen-Héderváry to resign in 1903, others regarded as their goal the opposition to the law favouring the use of the German language, and Ante Trumbić argued for the political alliance of Croats and Hungarians during the 1903 session of the Dalmatian Sabor (Parliament). From the perspective of more recent history, it is hardly surprising that contradictory trends characterized the ideology of Southern Slavs. A few months before the "new course" of the Dalmatian Parliament, Milan Obrenović, the pro-Vienna Serbian king, was assassinated and the Karadordevic dynasty opted for a pro-Russian orientation. Without much exaggeration it could be argued that Yugoslav nationalism was developed at least partly by artists. In 1910 the Dalmatian-born sculptor Ivan Mestrović (1883-1962) and some of his colleagues arranged an exhibition in Zagreb under the title "Despite Unheroic Time" to promote the Kosovo myth. The next year Mestrović, officially an Austrian citizen, exhibited in the Serbian pavilion in 
Rome, thereby expressing his protest against the Dual Monarchy. Still, not all Croats joined Yugoslavism. After the assassination of Franz Ferdinand by a member of "Mlada Bosna", a terrorist organization under Serbian influence, some Croats fought against Italy, Russia, and even Serbia. The Croatian parliament never ratified the establishment of the Kingdom of Serbs, Croats, and Slovenes, declared by Aleksandar Karadordevic on 1 December 1918.

History is liable to reinterpretation. This is especially true of the intellectual climate of the period of Pavao Rauch, appointed as Ban of Croatia by the Emperor in 1908. Robert Seton-Watson (1876-1956) described this Ban's régime as a perfect example of Hungarian repression (Seton-Watson 1912, 6-8), whereas a recent Croatian interpretation ascribes reforms to Rauch that led not only to "improvements to workers' social insurance, the slowing down of emigration, and the care given to the improvement of agriculture" but also to the strengthening of cultural autonomy (Kolar 2003, 154). "The evidence shows that the rule of Pavao Rauch had not been pro-Hungarian but that he worked in the interests of Croatia" (Kolar 2003, 156). This conclusion contradicts not only Seton-Watson's description but also a Hungarian historian's description of the Scottish publicist as a "scholarly historian" and a "typical "seeker of truth"' (Jeszenszky 1986, 325, $305)$.

It is virtually impossible to decide to what extent German nationalism could be considered a reaction against Pan-Slavism. Georg von Schönerer (1841-1921), the author of a manifesto for a "Verein der deutschen Volkspartei", written in 1881, was the son of a man who had built Austria's first railway in 1828 and who in 1860 received his patent of nobility from the hands of the Emperor for his services. He combined German nationalism with demands for social justice. In the face of the growing Jewish immigration from Russia at the time of the pogroms, he turned to the United States for a legislative model for racial discrimination: the Chinese Exclusion Act of 1881. For some time Schönerer escaped censure by clothing his formulations in an anti-Russian dress that appealed to some people's fear of Slavic encirclement. He tried to seek a following in Northern Bohemia, where German workers "met competition from Czechs who were willing to work in poorer conditions for less pay" (Janik and Toulmin 1973, 57).

There is no denying that aside from the strategic interests of the Western powers the main cause of the end of the Dual Monarchy was nationalism, whether Slavic or German. As a British historian remarked,

the crime committed by one young Bosnian in Sarajevo was hatched in a secret society, the Black Hand, which had been nourished on the idea of tyrannicide; it reflected the backward society from which it came (Mason 1985, 70).

The combination of the two factors was "neither inevitable necessity nor purely accidental" (Romsics 2001, 78). 
Much comment on the Dual Monarchy "has been coloured by the knowledge of its political collapse" (Mason 1985, 30). There was a sense of decadence in the art and literature of the region, but the same feature was also characteristic of the culture of other European countries, including late Victorian Britain and fin-de-siècle France. Undeniably one of the works about the decline of the West was Entartung (1893), a book published in Berlin that became widely influential in English translation as Degeneration. Its author used the pen name Miksa (Max) Nordau (1849-1923). Born in Pest to an Orthodox family, he settled in Paris in 1880, published his articles in the daily Pester Lloyd (started in 1854), and later became the co-founder of the World Zionist Organization.

\section{The Role of Jews in the Culture of the Monarchy}

It is widely known that Jews made a significant contribution to the culture of the Austro-Hungarian Empire. "The proportion of Jews or men of Jewish origin among University professors, medical men, and lawyers was very high," observed Karl Popper about his native Vienna (Popper 1982, 105), and one may add that if in the Austrian capital Jews "constituted five per cent of the city's population" (Janik and Toulmin 1973, 59), Budapest had an even larger Jewish community by the early twentieth century. The majority of Hungarian Jews lived in the capital, "they constituted 20 percent of the population" (L. Nagy 1994, 39).

Austrian Jews assimilated to German culture. In 1919, when the architect Adolf Loos (1870-1933) asked Schönberg to contribute to the drafting of the program of the newly established "Kunstamt" (Ministry of Art), the composer started his short essay with sentences that implied an unqualified identification with the German nation:

The most important task of the music section is to ensure the German nation's superiority in the field of music, a superiority which has its roots in the people's talents. These may stem from the fact that in former times the German elementary school teacher was nearly always also a music teacher (Schoenberg 1984, 369-370).

In the Czech lands the Jewish bourgeoisie preferred to belong to the German-speaking minority. Franz Kafka (1883-1924) was sent to a German "Gymnasium" (state grammar school) and studied at the German university of Prague. All his works, including the nouvelle Die Verwandlung (Metamorphosis, 1912), the unfinished Der Prozeß (The Trial, written 1914-15), the short story Ein Landarzt (A Country Doctor, written and published 1917), and the novel Das Schloß (The Castle, written 1921-22), were composed in German. His writing is heavily indebted to German Romanticism: Die Verwandlung recalls several tales 
of metamorphosis in the Grimm brothers' collection and Ein Landarzt to stories by E. T. A. Hoffmann. The interpretations of the Prague-born novelist, short-story writer, playwright, and critic Max Brod (1884-1968), which ignored the links between Kafka's works and German Romanticism, reduced the message of the two novels to their (allegedly) theological meaning by overemphasizing the presence of the Jewish legacy in Der Prozeß and Das Schloß. Both works have suffered from one-sided, allegorical readings. As an English critic observed with good reason, "the great reputation of Kafka began through accounts by foreigners who were more interested in ideas than in language" (Gray 1973, 3).

Before World War I the assimilation of the Jews seemed rather unproblematic in Hungary, where nationalism was fuelled by the memory of the suppression of the 1848-49 revolution, which had been supported by many Hungarian Jews. In 1881 an anti-Semitic member of the Hungarian parliament reported the disappearance of a Christian girl named Eszter Solymosi from the village of Tiszaeszlár. A ritual-murder allegation led to a public trial. The Liberal lawyer Károly Eötvös (1842-1916) won the case for the Jews. The anti-Semitic party was dissolved, the parliament passed a law in 1895 recognizing Judaism as equal to the other religious denominations, and in 1904 Eötvös published his detailed account of the trial under the title $A$ nagy per (The Great Trial). The fact that the Hungarian banking system and later even the war industry were controlled by Jews proves that assimilation could be pursued not only along the road of culture, but from our perspective it is more important to remember that the German publishers were gradually replaced by Jewish ones. For all but the last five years of its existence (from 1890 to 1919) the magazine $A$ Hét (The Week) was edited by József Kiss (1843-1921), a poet of Jewish descent. Huszadik Század (Twentieth Century), the chief organ of the quickly developing social sciences, was edited by Oszkár Jászi (1875-1957), a fully assimilated Jew, and Nyugat (West, 1908-1941), the literary periodical associated with the new generation, was largely sponsored by Jewish industrial magnates.

The examples of Ludwig Wittgenstein and György Lukács (1887-1971) indicate that intellectual life was not a substitute for the life of action: the fathers were successful businessmen and their sons became celebrated philosophers. Karl Popper's autobiography gives some idea of the growing division of the Jewish community:

My parents were both born in the Jewish faith, but were baptized into the Protestant (Lutheran) Church before any of their children arrived. (...) This, however, meant giving offence to organized Judaism. (...) assimilation worked. (...) But racial pride is not only stupid but wrong, even if provoked by racial hatred. All nationalism or racialism is evil, and Jewish nationalism is no exception (Popper 1982, $105)$. 
The last words may refer to Zionism. The founder of that movement was born in Pest. Most of the publications on Tivadar Herzl (1860-1904) have the fundamental weakness of ignoring the historical background of his upbringing. He was raised in a family that profited from the advantages of Hungarian Liberalism. In 1848 his uncle joined the Hungarian revolution which in 1849 led to a parliamentary decision to emancipate Jews. The young Tivadar, however, was one of those who refused to assimilate to Hungarian culture. Even a more moderate form of enthusiasm for German culture in the cases of the poet, playwright, essayist, and film theoretician Béla Balázs (originally Herbert Bauer, 1884-1949) and the philosopher György Lukács led to alienation from some Hungarians. The tragedy of the holocaust has made many forget that in the early twentieth century anti-German and anti-Jewish feelings sometimes went together among Hungarians who wanted to escape from the political and cultural influence of Vienna. Having no desire to have any contact with Hungarian culture, Herzl went to study at the University of Vienna. For a while he was even attracted to German nationalism and to socialism. He moved to Zionism only in 1895 , after he had covered the case of Alfred Dreyfus as the Paris correspondent of Die Neue Freie Presse. Interestingly, Richard Wagner's influence must have contributed to Herzl's plans for a Jewish state. As he wrote in his diary: "Moses' exodus would compare (to mine) like a Shrove Tuesday Singspiel of Hans Sachs to a Wagnerian opera" (quoted in Schorske 1980, 163).

As the feuilleton editor of the Neue Freie Presse, Herzl was largely responsible for the introduction of a genre that originated in French journalism. The limitations of this genre, its tendency to subjectify the objective, made intellectual rigour impossible. Together with the "Volksstück", the operetta, the well-made play, the occasional verse, and the pot-boiler novel, it represented popular culture.

The statement that Jews played a prominent role in the culture of the Monarchy is a somewhat overworked platitude today. It is not always remembered that the Jews of the Monarchy did not constitute a homogeneous community, and occasionally their contribution is emphasized to the detriment of the appreciation of non-Jewish scientists or artists. The following argument, for example, cannot be sustained:

the Jews were allied to those few outstanding intellectuals behind whom there stood nobody, especially not the Christian middle classes, a social stratum utterly hostile towards these intellectuals.

The characterization of "the Hungarian gentry that gambled away their (or, rather, their bourgeois wives') money" (Forgács 1994, 318) belongs to the legacy of a historiography that claimed to be Marxist. Péter Beniczky, who hired Gustav Mahler (1860-1911) in 1888, and Jenő Péterfy (1850-1899), the outstanding critic who praised Mahler's activity in the Budapest Opera House, belonged to the 
gentry (Szegedy-Maszák 2007, 187), and at least three of the leading poets of the periodical Nyugat: Endre Ady (1877-1919), Mihály Babits (1883-1941), and Dezső Kosztolányi had a similar background. "Hungarian culture both in its origins and in its character is the culture of the nobility", Babits claimed in 1939 (Babits 1978, 2: 621), strenuously defending a legacy that survived into the twentieth century. This declaration gave rise to a feverish debate during World War II, when some writers and artists relied heavily on the cultural heritage of the peasantry. Today all this is a closed chapter in history: both the gentry and the peasantry have disappeared. Whatever limitations the lesser nobility may have had, its lasting achievement cannot be denied. In Hungary this class constituted a considerably more numerous layer of society than in other European countries, with the possible exception of Poland. In 1848-49 most of the leaders of the revolution who wished to abolish the privileges of the ruling class and emancipate Jews belonged to that class. The culture of the Dual Monarchy cannot be separated from the life style of the gentry.

The thesis that Herzl's Zionism was "the result of his own initial anti-Semitism" (Janik and Toulmin 1973, 59) may be far-fetched, but Jewish self-hatred has a claim to consideration. Otto Weininger's (1880-1903) Geschlecht und Character (1903, translated as Sex and Character) was appreciated not only by Karl Kraus (1874-1936), one of the writers of Jewish parentage who were born in Bohemia and moved to Vienna. It is not absurd to believe that this work may "have had some influence on Wittgenstein" (Popper 1982, 1). This eminent philosopher's comments that "tragedy is something un-Jewish", Jews are "reproductive", and Mahler's music, in contrast to Arnold Bruckner's (1924-1896), is "worthless", "bad" (Wittgenstein 1980, 1, 38, 18-19, 67), and the opposition between invention and reproduction may derive from Weininger's idea that the Aryan race is the embodiment of the masculine-creative, while the feminine-reproductive principle corresponds to Jewish culture. In 1931 Wittgenstein mentioned Weininger as one of his sources, together with Boltzmann, Hertz, Schopenhauer, Frege, Russell, Kraus, Loos, Spengler, and Straffa. His argument that he himself borrowed everything from others may be linked to a nostalgia for tradition:

Tradition is not something one (Einer) can learn; not a thread he can pick up when he feels like it; any more than one can choose one's ancestors (Wittgenstein 1980, 19, 76).

Such an approach to tradition is strikingly similar to that of Schönberg:

my music, produced on German soil, without foreign influences, is a living example of an art able most effectively to oppose Latin and Slav hopes for hegemony and derived through and through from the tradition of German music" (Schoenberg 1984, 173). 


\section{The Impact of Socialism on Culture}

One of the paradoxes of history is that Jews both contributed to and undermined the formation of what could be regarded as the specific culture of the Dual Monarchy. Socialism as an international ideology was as responsible for the end of Austro-Hungary as nationalism, and some Jews believed that socialism could make it possible for them to become politically active. In Vienna the Social Democrats founded a party in 1889. The Prague-born Victor Adler (1852-1918), the man whose party had become the largest political organization in the Reichsrat by the beginning of the twentieth century, was of Jewish origin.

Zionism emerged in the wake of the rapid and large-scale assimilation of Jews. In so far as Jews did not seem to aspire to the status of a nation, they helped the integration of the Empire. By the end of the century, however, some joined international socialism, which in the long run contributed to the end of the Monarchy.

During the First World War there was an influx into Vienna of Jewish refugees from the old Austrian Empire, which had been invaded by Russia. These 'Eastern Jews', as they were called, had come straight from virtual ghettos, and they were resented by those Jews who had settled down in Vienna; by assimilationists, by many orthodox Jews, and even by Zionists, who were ashamed of those they regarded as their poor relatives (Popper 198, 106).

Shortly after the resignation of Charles IV, the last Habsburg monarch, the Communist leaders of independent Hungary put the industrial magnates in jail. On both sides the majority was Jewish.

In the spring of 1919 even Karl Popper had converted to Communism, but after a few months he became an anti-Marxist. Several decades later he remembered this period in the following manner:

It took me some time before I recognized (...) that the attempt to realize equality endangers freedom; and that, if freedom is lost, there will not even be equality among the unfree (Popper 1982, 36).

This confession clearly shows that Popper was not familiar with one of the outstanding works of Central European Liberalism by one of those responsible for the foundation of the Dual Monarchy. The first volume of Der Einflu $\beta$ der herrschenden Ideen des 19. Jahrhunderts aufden Staat by József Eötvös (18131871) was published in Vienna in 1851 , followed by a second volume that appeared in Leipzig in 1854. One of the main theses of this outstanding work is that equality and liberty are incompatible.

József Eötvös, a titled aristocrat, fought as strongly for the emancipation of Jews as his namesake Károly Eötvös. Although anti-Semitism was much stronger in the Western than in the Eastern half of the Monarchy, the downfall of Schönerer 
testified to the strength of Austrian Liberalism. When he broke into the offices of the Neues Wiener Tagblatt and beat up its staff he lost his title and was sent to prison. "When his party dissolved in 1889 it had only twelve hundred members" (Levy 1991, 113). Up to World War I German nationalism seemed to be a lame duck in comparison with socialism, although it is quite possible that some Jews joined the international movement out of fear of German imperialism.

Needless to say, it would be a gross exaggeration to say that all the major socialists were Jewish. From 1903 on the Czech Jaroslav Hašek (1883-1923) was a member of Prague anarchist circles. In 1915 he was called up, promoted, and won a medal. Having become a Russian prisoner of war, he joined the Czecho-Slovak Legion and eventually the Red Army. He is best known for creating the character Švejk, a cunning fool who appears in Dobry voják Švejk a jiné podivné historky (The Good Soldier Švejk and Other Strange Tales, 1911), Dobry voják Švejk v zajeti (The Good Soldier Švejk in Captivity, 1917), and Osudy dobrého vojáka Švejka za svétové války (The Fortunes of the Good Soldier Švejk in the Great War, 1921-1923). Švejk has become a quasi-mythic Central European type, a character resembling the heroes of picaresque narratives. His creation had been prepared in the popular anecdotes and feuilletons (some 1,500 short texts) published by Hašek before the Great War.

A far cry from Hašek's popular prose is the work of Lajos Kassák (18871967), poet, prose writer, and visual artist. The son of a technician in a pharmaceutical laboratory, he left school at the age of twelve. Five years later he moved from his native Érsekújvár (today Nové Zámky, in Southern Slovakia) to an industrial suburb of Budapest, where he became acquainted with the working-class movement. In 1909 he took a boat to Vienna, then walked to Paris via Germany and Belgium, and then was expelled from France as a vagrant. This trip is recounted in A ló meghal a madarak kirepülnek (The Horse Dies the Birds Fly Out, 1922), a long free-verse poem, and in the prose autobiography Egy ember élete (The Life of a Man, 1928-1939), a work that sheds light on the life of the working class in the last phase of the Monarchy. In 1913 he joined the Hungarian Social Democratic Party and two years later founded A Tett (Action), an international avant-garde journal in Hungary. After it was banned in 1916 because of the pacifist materials that had been published in its pages, he started a new periodical entitled Ma (Today). When Béla Kun, the leader of the Hungarian Commune of 1919, called $M a$ "a product of bourgeois decadence", Kassák protested in an open letter. As a result $M a$ was banned in July 1919 by the Communist authorities.

Kassák's free verse and Constructivist paintings represent an internationalism that is radically opposed to Christian Socialism, an Austrian movement led by Karl Lueger (1844-1910), a man of humble origin who became the mayor of $\mathrm{Vi}$ enna in 1897. Unlike German, Slavic, or even Hungarian nationalism, Zionism, or Social Democracy, his movement strengthened integration within the Monarchy. 
Today there is a square named after Dr. Karl Lueger at the point where the Stuben Ring and the Schubert Ring meet. Some may view this fact as a sign of Austrian opportunism. Undeniably, this mayor manipulated the anti-Semitic feelings of some lower-class citizens. He reputedly referred to the Hungarian capital as "Judapest", but his "dislike of Hungarians was stronger than his dislike of Jews" (Lukacs 1988, 95). His aversion to Hungarians and Jews as communities that would weaken the Habsburg Empire made a great impact on Hungarian intellectuals, as is clear from Timár Virgil fia (The Son of Virgil Timár, 1921), a short novel by Mihály Babits. "Let him go to Judapest, where he belongs", says a right-wing Roman Catholic priest teaching in a provincial town about a boy of partly Jewish origin, a student who is under the influence of superficial Liberal publications coming from Budapest (Babits 2001, 87).

Once more, the complexity of history can be illustrated by the fact that the statue adorning Dr. Karl Luegerplatz was put up by a Social Democratic administration after World War I in memory of the second most popular citizen of the Monarchy, a politician who with his ambitious program of public works had achieved much for his own class, the lower bourgeoisie. Thanks to him the British gas company that supplied Vienna was replaced by a native firm, public transportation and the water system were improved, and orphanages, hospitals, and schools were built.

\section{Trends in the Visual Arts and Music}

Lueger's activity was badly needed at the time of the rapid growth of the population of the imperial capital, "from 476,220 in 1857 to 2,031,420 in 1910" (Janik and Toulmin 1973,50). Most of the public buildings and apartment houses of the Ring that separates the inner city from its suburbs were built in the decades following the Compromise between the Emperor and the Hungarians. The Rathaus (City Council Building), designed by Friedrich Schmidt, was built in the years 1872-1883; the Hofburgtheater (Imperial Theatre), designed by Gottfried Semper and Carl Hasenauer, between 1874 and 1888; the University, designed by Heinrich Forstel, between 1873 and 1884; and the Reichstrat (Parliament), designed by the Danish Theophil Hansen, between 1874 and 1883. The political, educational, and cultural functions of these public buildings symbolized the rise of the bourgeoisie in contrast to the churches, the Hofburg, and the aristocratic palais of the inner city. The eclecticism of the Ring marked a departure from the Gothic style of the Cathedral of St. Stephen and the baroque architecture of the Burg. In 1914, "72 of the Weierstrass's 478 privately owned buildings were in the hands of corporate owners" (Schorske 1980, 60). Sometimes it is suggested that the eclecticism of the Ring was in sharp contrast with the later Art Nouveau. This is a simpli- 
fication. One should recognize a partial continuity in the motives behind the partly pseudo-Greek, partly pseudo-Roman Reichstrat, the neo-Renaissance University, the neo-Baroque Burgtheater, and the neo-Byzantine style in some paintings by Gustav Klimt (1862-1918). Having made his fame as a representative of history painting, after his two visits to Ravenna, where he viewed the mosaics of San Vitale, he turned to Byzantine mosaics for inspiration when subscribing to a two-dimensional sense of space. In 1886-1888, together with his brother Ernst and Franz Matsch he made a series of ceiling paintings for the grand stairway of the Burgtheater. In 1888 the City Council commissioned Gustav Klimt and Franz Matsch to paint the auditorium of the old Burgtheater with such illustrious figures as the actress Katharina Schratt (the Emperor's mistress), Lueger, and the famous surgeon Theodor Billroth. Two years later he was awarded the Emperor's Prize. The following year Klimt was asked to decorate the Kunsthistorisches Museum and in 1894 the Ministerium für Kultur und Unterricht (Ministry of Culture and Education) invited him to design three ceiling paintings for the hall of the University. By the time he executed this commission (1898-1904) Klimt had become the leader of the Secession movement, a group of nineteen artists which had its first show in 1897. In 1900 the movement was represented at the Paris International Exhibition. The fact that Klimt was commissioned to make mosaics for the Palais Stoelet in Brussels (1910) was further proof that Austrian Art Nouveau met with international recognition.

Like the Pre-Raphaelites, the Viennese Art Nouveau artists met with some resistance, but represented a fully institutionalized trend that evolved gradually from the official culture of the state. The major catalyst in this process was the impact of Richard Wagner and Friedrich Nietzsche. One of the University ceiling paintings, Philosophy (1900), clearly refers to Erda in Das Rheingold and to "Das andere Tanzlied", a poem at the end of Part III in Also sprach Zarathustra, a text set to music by Gustav Mahler, in the second movement ("Sehr Langsam. Misterioso") of the "Zweite Abteilung" of his Third Symphony, composed in 1895-1896 and first performed in 1902.

In his later career Klimt was also supported by the haute bourgeoisie. He painted a series of portraits, among them one of Margaret Stonborough-Wittgenstein (1905, Neue Pinakothek, Munich), sister of the philosopher. In his portrait both the person of the subject and the environment referred to earlier art: in the Portrait of Fritza Riedler (1906, Österreichisches Galerie, Vienna) the window that frames the subject's face resembles the headdress in Velázquez's Portrait of Queen Mariana of Austria (1646), while the geometrical forms of the dress and the background in the first version of the Portrait of Adele Bloch-Bauer (1907, Österreischisches Galerie, Vienna) derive from the abstract cells on Byzantine mosaics. When Klimt was criticized from the perspective of Classical Greek art, he was defended by the outstanding historian Franz Wickhoff (1853-1909), who 
rehabilitated late Roman art and argued for a cultural relativism. What he, together with Alois Riegl (1858-1905), suggested was that the history of art could not be interpreted in terms of progress and decadence. If Klimt's paintings seemed to depart from the norms of certain historical periods, they also established continuity with other eras.

Borrowing historical style also characterized the architecture of Budapest. It was only in the twentieth century that such eclecticism was questioned in the name of functionalism. In 1918 the art historian Lajos Fülep (1885-1970) published an essay condemning both Semper and his Hungarian contemporary Miklós Ybl (1814-1891) for an emphasis on "style' to the detriment of structure", for "a mistreatment of the materials and the absence of construction". In his view the so-called "second Renaissance" of Semper and Ybl ignored the function of the buildings, and their eclecticism led to "an awful collection of apartment houses that imitated Renaissance palais" (Fülep 1974, 1:277, 280-281). This attack was made at a time when the functionalism that culminated in the Bauhaus promised to introduce radically new ideas in urban planning. The twentieth century, with its totalitarian regimes, failed to realize such plans and the present age may look upon the buildings of the Budapest Customs House (1870-1874) and the Opera (1875-1885) with more favourable views. In comparison with Vienna,

Budapest's late start in development actually had certain advantages, allowing the use of new technical means and the adoption of modern, liberal-spirited ideas of city politics,

observed one historian (L. Nagy 1994, 49), and another went even further in emphasizing the regional role of the city by claiming that during the last three decades of the nineteenth century it

was the fastest growing city in Europe. From 1890 to 1900 its population increased by more than 40 percent. In 1900, with a total of 733,000 people, it had become the sixth largest city of Europe, and the largest one between Vienna and St. Petersburg (Lukacs 1988, $67)$.

This may explain why the Hungarian capital (after the unification of Pest, Buda, and Óbuda in 1873) had become a more important cultural centre than Prague, a city with a more illustrious past.

From the perspective of the twenty-first century continuity seems more striking than discrepancy between the eclecticism of the later nineteenth century and the Art Nouveau of the years around 1900. Camillo Sitte's (1843-1890) critique of the Ring, expressed in his book Der Städtebau (City Building, 1889), is as redolent with nostalgia for the vanished past of artisan and craft culture as the ideology 
of Ruskin and the Pre-Raphaelites, whose cult of pre-industrialism became the starting point for Art Nouveau in Vienna, Prague, and Budapest.

Two European tendencies exerted a profound influence on the architecture of the Monarchy: the rise of art history and Richard Wagner's effort to create "Gesamtkunstwerke" ("total works of art"). Once again, continuity rather than rupture characterized the state of the arts: Gottfried Semper became Richard Wagner's theatre architect, the conductor and the scenery painter of the first Bayreuth performance of Der Ring des Nibelungen, the Hungarian János Richter (18431916) and the Viennese Josef Hoffmann (1831-1904) were members of Sitte's intellectual circle, in 1875 Sitte himself insisted on the importance of Richard Wagner's advocacy of artisan values in his address to the Vienna Wagner Society (Richard Wagner und die deutsche Kunst), and in 1883 he adorned the ceiling of the apartment he came to occupy as director of the new Trade School of Vienna with scenes from the tetralogy. The partly conservative, partly revolutionary ideal of the artist as the regenerator of culture embodied in Die Meistersinger von Nürnberg became the driving force behind the intellectual and artistic achievements of the Monarchy that represented a strong opposition to the utilitarianism of the rapidly growing business-oriented society of the late nineteenth century. Schönberg characterized his sextet Verklärte Nacht (Transfigured Night, composed in 1899) in the following way:

the thematic construction is based on Wagnerian 'model and sequence' above a roving harmony on the one hand, and on Brahms' technique of developing variation - as I call it - on the other (Schoenberg 1984, 80).

Such a reconciliation of the legacies of Richard Wagner and Johannes Brahms did not characterize all Austrian composers of the late nineteenth century; one of Wagner's great admirers, the outstanding late Romantic master of "leider", Hugo Wolf (1860-1903), for example, decried the symphonies of Brahms in his writings on music.

The recordings of the composer-conductor Pierre Boulez have shown that one of the links between Richard Wagner and the second Vienna school was Gustav Mahler. Schönberg "at first considered Mahler's themes banal" (Schoenberg $1984,455)$, but later discovered this composer's ability to elevate himself to resignation, his thinking for orchestra, and the melodic construction in his symphonies. In 1941 Bartók pointed out the decisive influence of Wagner in his First String Quartet (1908-1909), and scholarship has confirmed his opinion (Vikárius 1999, $49,104)$. Numerous examples could be cited to prove that for the sonata form Richard Wagner substituted the Leitmotiv, a structuring principle that even an opponent to German culture such as Janáček borrowed, and paved the way for the emancipation of (unresolved) dissonances. Composition with twelve tones meant 
a further step, a way of structuring that made Schönberg's school more radical than composition in other countries. He himself gave the following definition of the method of evolving the formal elements out of a twelve-tone "Reihe" ("row"), a medium of organization he used from 1921: "From the basic set, three additional sets are automatically derived: (1) the inversion; (2) the retrograde; and (3) the retrograde inversion" (Schoenberg 1984, 225).

Two of his pupils, the Viennese Anton von Webern (1883-1945) and Alban Berg (1885-1935) proved to be exceptionally original. In contrast to the monumental symphonies of Bruckner and Mahler, Webern's compositions are marked by extreme concentration. The third (Adagio) movement of Bruckner's Eighth Symphony (first performed in 1892) in a recording conducted by Pierre Boulez (Haas edition, DG 459 678-2) lasts twenty-four minutes and fifty-two seconds. The third piece in Webern's Sechs Bagatellen für Streichquartett (op. 9, composed between 1911 and 1913) lasts a mere twenty-two seconds in the interpretation of the La Salle Quartet (DG 419 994-2). Webern's Fünf Stücke für Orchester (op. 10, 1913) last four minutes and thirty-six seconds in a 1992 Boulez recording (DG 437 786-2). Four of the five pieces last less than one minute, and the duration of the second piece is thirty-nine seconds. In such works tone-colour is given a prominence unprecedented in Western music. In the words of Boulez, the stylistics of Webern "was revolutionary before and continued to be so after the row" (Boulez 1966, 372). The extreme brevity of his works, the use of large intervals and silence may be among the characteristics of his unique art that present difficulties for human perception. This is why his music has never met with a success comparable to that of Wozzeck, Berg's highly structured opera based on the dramatic fragments of Georg Büchner, composed between 1915 and 1921. This composer's "genius lay in resolving the tension existing between the idea of closed form and Wagner's continuous music-drama". The Leitmotiv plays a distinct role in this stage work, "really serving to elaborate forms and thus interpreting the dramatic and the musical thought" (Boulez 1986, 374-375).

In architecture the assault made on eclecticism comparable to the musical innovations of the second Viennese school and Bartók was launched in the last decade of the nineteenth century. In 1893 Otto Wagner (1841-1918) won a competition for a new development plan for the imperial capital. Two years earlier Ödön Lechner (1845-1914) and Gyula Pártos (1845-1916) won competitions with their plans for a City Council building in Kecskemét (in central Hungary) and for the building of a Museum of Applied Arts in Budapest. Both Otto Wagner and Ödön Lechner had successful historicism careers behind them. Otto Wagner's building of the Österreichische Ländesbank (1882-1884), for instance, has a Renaissance façade, and the apartment house Lechner designed for his father-in-law is in French Renaissance style (1871). 
Even Otto Wagner's initiative cannot be called a form of counter-culture. In 1894, after the death of Carl Hasenauer, he was appointed Professor of Architecture at the Academy of Fine Arts. Roughly in the years between 1894 and 1901 he worked as the chief architect of the Vienna railways system and designed more than thirty stations, as well as cuts, viaducts, tunnels, and bridges, giving a prominent role to function, engineered structures, and such building materials as iron, glass, aluminium, and concrete. In Moderne Architektur (1895) he anticipated Fülep's critique of historicism by arguing that in art every style emerged gradually from the previous one, so that eclecticism was an illegitimate way of filling a gap in history. Later developments undermined his argument. From a Postmodern perspective, Otto Wagner's idea of a linear development seems somewhat naive and dogmatic. Despite his commitment to technology, he was tempted to view art as a surrogate religion. Symptomatically, his younger associate Joseph-Maria Olbrich (1867-1908) was to design the House of Secession (1898) as a modernized temple.

The difference between the Art Nouveau architecture of Vienna and Budapest lay in some Austrians' hostility to ornament. The most important among them was Adolf Loos, born in Brünn. Although relatively few of his plans were actually realized - the Steiner House in Vienna (1910) is one of them -, his writings, in which he argued against decoration, became influential after World War I, when the Bauhaus architects gave primary emphasis to functionalism. In this sense, Lechner was much closer to the mainstream represented by Belgian German Jugendstil, the Glasgow School, Belgian, French, Scandinavian, or North American Art Nouveau.

Klimt's Salome (1909, Galleria d'Arte Moderna, Venice) and other paintings can prove that hostility to ornamentation was restricted to architecture. One of the distinguishing features of Klimt's art was the blurring of the distinction between figure and ornamental background. In fact, it could be added that the influence of this painter made even Otto Wagner contradict himself; gilded trees of life can be seen on the façade of his two adjoining Wienzeile Buildings (1898-1899).

Following the example of the British Arts and Crafts movement, the Art Nouveau artists in the major cities of the Monarchy succeeded in undermining the opposition between art and everyday life by putting a special emphasis on interior design and the applied arts. Czech glasses, art deco, metallic and crystalline objects of the Wiener Werkstätten, a crafts workshop established around 1903 and dominated by Josef Hoffmann (1870-1956), or the products of the ceramic factory of Vilmos Zsolnay (1828-1900) in Pécs, a city in Southern Hungary, transformed not only upper-class but even middle-class homes. Such periodicals as Magyar Iparmüvészet (Hungarian Applied Art, from 1897), Kunst und Kunsthandwerk, Ver Sacrum (both from 1898), Das Interieur (from 1900), and Wiener Werkstätten (from 1903) campaigned for a reconciliation between the aesthetic 
and the useful. The ideal of the Gesamtkunswerk inspired numerous artists to experiment with different media: Schönberg exhibited portraits and landscapes with the Expressionists, Oskar Kokoschka (1886-1980) published Die träumenden Knaben (The Dreaming Boys, 1908), a fairy tale in verse with colour lithographs, and Kassák designed his books.

If we want to assess the significance of the culture of the Dual Monarchy, we cannot help but conclude that it is more justifiable to emphasize the unity of conservatism and innovation in the intellectual and cultural scene than to speak of a conflict between them. Clear-cut distinctions and turning points are ruled out by two facts: the period since World War I has shown that the same intellectual phenomenon can be read as representing continuity or rupture, depending on the interpreter's historical perspective, and the innovator in one sphere often had retrograde views in another. To mention but one example, the satirist Karl Kraus, the founder and from 1913 sole contributor of the periodical Die Fackel (The Torch, 1899-1936) and the author of the visionary Die letzten Tage der Menschheit (The Last Days of Mankind, 1919), was consistently hostile to the painting of Klimt.

One of the shortcomings in the historians' interpretation of the legacy of the Monarchy is the underestimation of the stratification of culture.

In the second half of the nineteenth century, traditional opera became increasingly a minority interest; its élite audience of connoisseurs was able to follow it into the abstract and intellectual realm of Wagner and of post-Wagnerian music (Hanák 1994, 210 ).

Such generalizations can hardly stand. The notion of "traditional opera" does not apply in any relevant way to the complexity of the interrelations between the earlier tradition of Italian opera and the successful development of national schools there were as different from each other as French "grand opéra" and German "Singspiel. The concepts of "minority" and "élite" are vague in a sociological sense. More than terminology is at stake here. The relevance of the adjectives that are supposed to characterize Wagner's art is questionable in view of the musical and theatrical achievement that made the Bayreuth Festival a radically new institution. Wagner's influence transformed the attitude of the public in the Monarchy not only because of the composer's several stays in the Austrian and Hungarian capitals but also through the activity of such outstanding conductors as János Richter, Antal Seidl (1850-1898), and Gustav Mahler. Richter was the conductor of the opening performances in Bayreuth in 1876 and the first performance of Bartók's Kossuth Symphony in Manchester in 1904. Seidl led the campaign for Wagner's art in Zenészeti Lapok (Musical Letters, 1860-1876), published in Budapest, and conducted the first performance of the Ring in the Hungarian capital in 1883. Mahler's interpretations of Wagner during his stay in Budapest (1889-1891) and Vienna (1897-1907) set an exceptionally high standard. In Bu- 
dapest he staged most performances in Hungarian. While from the perspective of the present age this practice might seem questionable, around 1890 it certainly made opera more accessible to the wider audience. In Vienna Mahler worked together with the stage designer Alfred Roller (1864-1935), who was also born in Moravia. In Budapest the composer-conductor succeeded in convincing the audience of the importance of stagecraft and mise-en-scène, setting an example for Count Miklós Bánffy (1873-1950), who during World War I staged Bartók's first ballet $A$ fából faragott királyfi (The Wooden Prince) and in 1918 his only opera $A$ kékszakállú herceg vára (Duke Bluebeard's Castle) (Szegedy-Maszák 2007a, 180-181).

Both Roller and Bánffy were painters, and their work was closely related to Austrian and Hungarian Art Nouveau. The difference between the two was inseparable from a difference in attitude towards peasant culture. While Otto Wagner spurned folk art, Lechner made use of the ornaments of peasant objects. At the beginning of the twentieth century some regions of Hungary still had an archaic peasant culture rooted in the distant past. In the summer of 1904 Bartók heard old Hungarian folk songs for the first time in a village in Upper Hungary (today Southern Slovakia). In 1906 Lechner published a manifesto insisting that "the Hungarian national style had to be discovered in the culture of the Hungarian people" (Lechner 1906, 6). At the same time, he referred to Finnish art and the activity of Otto Wagner and the Wiener Werkstätten. His goals were similar to those of Bartók, who published Magyar népdalok (Hungarian Folksongs, 1906) for voice with piano accompaniment with his colleague Zoltán Kodály (1882-1967). The similarities with Janáček's collecting of Moravian, Slovak, and Czech folk songs are undeniable. Among the works of both Janáček and Bartók one finds harmonized versions, more or less radically modified arrangements of folk songs, and original works containing elements of folklore. The Moravian composer's endeavour to instil into the future teachers a love of folk music which they could then pass on to the children in schools parallels Kodály's efforts to change education in music.

\section{Literature and the Other Arts}

Nevertheless, an overemphasis on folklorism would lead to distortion. Just as Bartók's second ballet, A csodálatos mandarin (The Miraculous Mandarin, completed in 1919) begins with an explicit imitation of the noises of the metropolis, in the same way, urbanization made a great impact on Hungarian literature. A literary historian cannot quite agree with the statement that the 
city of the big tenements and brownstone schools, of the eclectic and ambitious public buildings, of millenary monuments and broad avenues does not surface in the pictures painted or stories told of Budapest (Forgács 1994, 317).

Counter-examples abound, especially in short fiction, but there are also novels that present life in the metropolis. A püspök atyafisága (The Bishop's Relatives, 1889), Ödön Iványi (1854-1893) has scenes in such public buildings as the Parliament and the Stock Exchange; Midás király (King Midas, serialized in 18911892) by Zoltán Ambrus (1861-1932) is about everyday life in an apartment house; Budapest (1901) by Tamás Kóbor (1867-1944) is a naturalistic "tranche de vie" about the less prosperous of the two Jewish districts of the city; A kristálynézök (The Crystal Gazers, 1914) by Kálmán Harsányi (1876-1929) is a roman à clef about the different intellectual circles of Budapest, including the members of the urban Art Nouveau group centred around Lechner. One of the most successful playwrights of the period, Ferenc Molnár (1878-1952), published several prose narratives about Budapest, including A Pál utcai fiúk (The Boys of Pál Street, 1907), a widely read and translated novel about one of the industrial districts of the city. The influence of urbanization was so strong that even Jókai felt an obligation to devote a work to the life of the petty bourgeoisie; Gazdag szegények (The Wealthy Poor, 1890) was even put on stage in 1893. Gyula Krúdy (1878-1933), a highly original and extremely prolific Hungarian writer, published numerous works of fiction about the Hungarian capital, including $A$ vörös postakocsi (1913, translated as The Crimson Coach), a novel about actresses. With the advent of the avant-garde links between urbanization and art became even closer. Kassák's free-verse poem Mesteremberek (Craftsmen, 1915) is a collective monologue of workers. A Keleti Pályaudvar éjjel (The Eastern Train Station at Night, 1902), by Tivadar Csontváry Kosztka (1853-1919), a major painter whose work represents a transition from Art Nouveau to Expressionism, portrays one of the new public buildings of a rapidly changing city. Advertisement was also transformed, and the painters who made posters tried to bridge the gap between high and popular art. The Hungarians who cultivated this genre were inferior to the Czech Alphonse Mucha (1860-1933), who spent much of his early life in Paris, the birthplace of the poster, although he was also one of the founders of Ver Sacrum.

New forms of popular culture developed almost imperceptibly out of old genres, especially in literature. The "Volkstück", a form of popular entertainment cultivated by the Viennese Nepomuk Nestroy (1801-1862) and the Hungarian Ede Szigligeti (1814-1878), was transformed into such musical comedies as János vitéz (John the Hero, 1904). It is based on Petöfi's celebrated verse tale (1844), and music was composed by Pongrác Kacsóh (1873-1923). The success of this work was largely due to the acting of Sári Fedák (1879-1953), who sung the male title role. She was one of the most talented actresses of the early 20 th century. 
(Sadly enough, at the end of her long and spectacular career she was deported by the Communists.)

Although several composers of the so-called Viennese operetta were Hungarian, the works of Ferenc Lehár (1870-1948) and Imre Kálmán (1882-1953) contained fewer "Hungarian" elements than Der Zigeunerbaron (The Gypsy Baron, 1885 ) by Johann Strauss Jr. (1825-1899), the libretto of which was based on a story by Jókai. Schönberg's main charge against this kind of popular music was that it asked for no mental (intellectual and emotional) effort. It "accommodated (...) to the popular feeling" and thus concealed the fact that "unvaried repetition" was "cheap" (Schönberg 1984, 128, 131). As early as 1909 he insisted that market-value was "irrelevant to intrinsic value". His rejection of popular culture became even more unqualified after he had been forced to settle in the U. S.: "if it is art, it is not for all, and if it is for all, it is not art", he insisted, and he added: "Popular music speaks to the unsophisticated, to the people who love the beauty of music but are not inclined to strengthen their mind" (Schönberg 1984, 190, 124, 134). Such a conception implies that popular culture is characterized by addition, mere juxtaposition, and unmodified repetition, potpourri (a randomness that may remind some of what is meant by "bricolage" nowadays), whereas high culture is distinguished by "variation and development". In short, "the laws of art work in a way that contradicts the way the popular mind works". Serious art followed the principle of "never repeating without varying" (Schoenberg 1984, 265, 299, 480).

Much of the literature of the age could not meet such high standards. The literature that was published often relied on oral culture. Jókai was a passionate collector of anecdotes. Many of them appeared in the comic weekly Üstökös (Comet, 1858-1918). Two of its successors, Borsszem Jankó (1868-1936), read mainly by the lower middle-class, and Kakas Márton (1894-1914), were responsible for the development of jokes. In its best period Borsszem Jankó was edited by Adolf Ágai (originally Aigner, 1836-1916), an assimilated Jew. Between 1870 and the early $1890 \mathrm{~s}$ it had a readership of 15,000-20,000. It often ridiculed the national minorities (including Jews). The most popular figure of Kakas Márton was the village mayor Gábor Göre, created by Géza Gárdonyi (1863-1922), the author of plays, short stories, and Egri csillagok (The Stars of Eger, 1901), a very popular historical novel about the Hungarians' struggle against Ottoman occupation in the sixteenth century.

In certain respects Budapest could not help imitating Vienna. The Ring and the café represent two forms of public space that played a major role in the literary and artistic life of both cities. They are the location of the first two scenes in the above-mentioned Die letzten Tage der Menschheit by Karl Kraus, a satirical "tragedy" in five acts that incorporates speeches and editorials from the newspapers. 
The café represented journalism and the Ring public institutions; the two were so closely interconnected that the one without the other seemed of no avail. The huge conglomeration of scenes that Kraus composed with the intention of presenting World War I in the form of an apocalyptic vision is closely related to journalism; several parts were published in Die Fackel before the whole work appeared as a book. If Weininger represented self-hatred, Kraus exercised another form of self-criticism: one of the targets of Die Fackel was journalism, the narcissism of feuilleton writing, the press and especially Die neue freie Presse, the most popular Viennese newspaper, which was infiltrated by political and business interests.

In Vienna and Budapest artists and writers spent most of their time in cafés and clubs. Peter Altenberg (originally Richard Engländer, 1859-1919), whose five "Ansichtskartentexten" ("picture postcard texts") Alban Berg set to music in 1912, for instance, lived in the Café Central. Both the poet Ady and the prose writer Krúdy used the café as their workplace.

It was only in 1914 that an important difference became manifest in the attitudes of the Austrian and Hungarian artists and writers. Among the Hungarians most were reluctant to fight for the Monarchy, whereas among the Austrians there were many who were ready to participate in the war.

When the First World War began [Schönberg declared in 1950], I
was proud to be called to arms and as a soldier I did my whole duty
enthusiastically as a true believer in the house of Habsburg, in its wis-
dom of 800 years in the art of government and in the consistency of a
monarch's lifetime, as compared with the shorter lifetime of every
republic. In other words, I became a monarchist. Also at this time and
after the unfortunate ending of the war and for many years thereafter,
I considered myself (...) a quiet believer in this form of government,
though the chances of a restoration were at zero (Schoenberg 1984,
505-506).

Because of his strong attachment to the Monarchy, Kokoschka joined an élite corps of the Imperial Cavalry in 1915. He felt convinced that for someone whose life and work were deeply rooted in the traditions of the Monarchy it was a natural obligation to fight for the survival of that state. His vision of the Monarchy resembled that of Stefan Zweig, and his approach to tradition was similar to that of Schönberg and Wittgenstein. In 1949, in a letter to an English student, he himself explained that his art originated in the Baroque culture that "was still a tradition alive" in his boyhood. He named Maulbertsch, Daniel Gran, Kremser Schmidt, the sculptor Matthias Braun, the architects Fischer von Erlach and Hildebrandt as his masters.

This Baroque culture, of which still thousands of humble votives, shrines and crucifixes on the crossroads are witnesses, has saturated 
me with the same mystic vein as you and your friends find in El Greco (Kokoschka 1992, 204).

Additional evidence of the ambiguity of the opposition of modern versus conservative could be the activity of Max Reinhardt (originally Maximilian Goldmann, 1883-1943). Although he was born in Vienna, his first great success was a production of $A$ Midsummer Night's Dream in the Deutsches Theater Berlin in 1905. Karl Kraus saw superficiality in Reinhardt's works. If one watches the film version Reinhardt co-directed in 1935, this criticism cannot be dismissed as entirely illegitimate, although it is possible that after his emigration to the U. S. the director had to make concessions to popular taste. His early productions represented a reaction against naturalism. In 1906, in the Berlin Kammerspiele, which had no more than four hundred seats, he produced Ibsen's Ghosts with stage design by Edvard Munch, the Norwegian forerunner of Expressionism. The photographs that have survived suggest that his staging of the German writer Karl Vollmöller's The Miracle (London 1911, Vienna 1912) was characterized by remarkable visual effects. His plan to start a Festival in Salzburg with Hugo Hofmannsthal (1874-1929), was delayed by World War I. Kraus's attack on the first performance of Jedermann (Everyman) was at least partly directed against the text, Hofmannsthal's 1911 rewriting of the late medieval English morality. Other theatrical experts were impressed by the way the Baroque sculptures of the Cathedral Square were transformed into the allegorical characters of the play.

In retrospect, Alfred Roller, who sometimes worked together with Reinhardt, might seem a less spectacular but more sophisticated artist. The surviving visual and verbal documents suggest that during his association with Mahler in the Vienna Hofoper (from 1903 on) his productions were highly innovative in their handling of the interrelations of space, colour, light, music, word, and gesture. He excelled not only in the interpretation of Richard Wagner's works; his Don Giovanni, first created on 21 December 1905, was especially original: the transformations of the same columns served as the background to all the scenes.

No less remarkable was the activity of the Polish Stanisław Wyspiański (1869-1907). During his visits to Paris (1890-1894) he became acquainted with French painting and theatre. His portraits, paintings, and drawings, as well as his furniture and stained-glass designs represent a Cracovian variety of Art Nouveau. They served as a kind of background to his theatrical productions. He was no mere playwright. Both Wesele (The Wedding, 1901), his most popular work, and Wyzwolenie (Deliverance, 1903) ask for a wide range of extra-verbal effects, paving the way for avant-garde theatre.

It is often argued that the dramatic and narrative works composed in the Dual Monarchy owed their inventiveness to the impact of psychoanalysis. Those who turn to psychoanalysis to explain art usually produce rather one-sided interpreta- 
tions. As I have pointed out elsewhere (Szegedy-Maszák 2007b), the fundamental difference between the short stories of Kosztolányi and his cousin Géza Csáth (originally József Brenner, 1887-1919) is that Kosztolányi kept a distance from the conclusions drawn by Sigmund Freud (1856-1939), whereas Csáth, himself a practising doctor, was increasingly tempted to reduce his tales to case studies. Kosztolányi had reservations about the value of psychoanalysis for art that were similar to those of Kraus. It was hardly accidental that this Hungarian author was one of the earliest translators of the verse of his Austrian contemporary.

Freud's literary contribution was twofold. He was a very prolific essayist who covered numerous fields, including the visual arts and literature. Several of his books exerted a decisive influence on literature. Die Traumdeutung (The Interpretation of Dreams, 1900) changed the treatment of dreams. One could cite numerous works, ranging from A gólyakalifa (literally The Stork Calif, 1913), a short novel about double identity by Mihály Babits, to La coscienza di Zeno (The Confessions of Zeno, 1923), by the Trieste-born Italo Svevo (pseudonym of Ettore Schmitz, 1861-1928), the Italian translator of Freud's above-mentioned book.

There is no denying that the rise of psychoanalysis went together with changes in the writers' approaches to their characters. Arthur Schnitzler, for instance, highlighted the life of instincts in a series of successful although somewhat superficial plays presenting sexuality as liberated from moral values. He also experimented with the interior monologue in such novellas as Leutnant Gustl (Lieutenant Gustl, 1901) and Fräulein Else (Miss Else, 1924). Csáth published a study on psychic complexes (Az elmebetegségek pszichikus mechanizmusa, The Psychic Mechanism of Mental Illnesses, 1911), and in Anyagyilkosság (Matricide, 1908) and other stories he tackled the manifestations of repressed sexuality. Caught between science and art, Schnitzler and Csáth produced provocative texts rather than finished works of art.

Csáth was a drug addict whose life ended in suicide. In his stories cruelty is often combined with deliberate artificiality and a sense of decadence, two characteristics that are manifest in the works of Hugo von Hofmannsthal, a fully assimilated Jewish poet, playwright, short-story writer, and essayist. His lyric Ballade des äusseren Lebens (The Ballad of Exterior Life, 1896) served as a model for Esti kérdés (Question at Night, 1908) by Mihály Babits. The Hungarian poem can be read as a palinode, a recantation of the earlier work. It is usually assumed that the Hungarian periodical Nyugat (West) expressed by its very name a desire to break loose from Vienna and turn to cultures beyond the German-speaking territory.

Budapest certainly made serious attempts to compete with Vienna. In the 1890s the painter József Rippl-Rónai (1861-1924) joined the group called "Les Nabis" in Paris. In the next decade the poet Ady visited the French capital and translated poems by Baudelaire, Verlaine, and Jehan Rictus for his verse collection Új versek (New Poems, 1906). The Transylvanian-born prose writer Dezső 
Szabó (1879-1945) published essays on Laforgue, Rimbaud, Verlaine (1911), Corbière, Paul Fort, and Marinetti (1912) in Nyugat, and Babits was an avid reader of the British poets of the late nineteenth century. Still, in his Esti kérdés the parallels with the syntactic structure and existential questioning of Hofmannsthal's Ballade is clear evidence of the similarities between Austrian and Hungarian poetry. The long essay on Rilke, published in Nyugat in 1909, claiming that "today Vienna means more in world lyrics than Paris, London, or Germany as a whole" (Kosztolányi 1975, 347), and the same poet's numerous translations of poems from Rilke's Das Stundenbuch (The Book of Hours, 1905), Das Buch der Bilder (The Book of Pictures, 92, 1906), and Neue Gedichte (New Poems, 1907) are further proof of the close link between the Austrian and Hungarian poetry of the early twentieth century. Although the word "rilkissimus" was applied to Kosztolányi in a newspaper article by Dezső Szabó in 1920 (Kosztolányi 1977, 640), the indebtedness of Kosztolányi's cycle of poems A szegény kisgyermek panaszai (The Laments of a Poor Little Child, 1910) to Rilke is far less direct in comparison with Babits's imitation of Hofmannsthal. Kosztolányi's war-time short story Káin (Cain, 1916) is a free and even distorted rewriting of the fifteen-line section of Das Stundenbuch that has the following inscription: "Der blasse Abelknabe spricht" ("The pale Abel speaks"). The poem is a monologue of the dead Abel, whereas the prose narrative is about a Cain who lives in contentment after the death of his brother.

In his essay Der Dichter und diese Zeit (The Poet and Our Age, 1906) Hofmannsthal formulated the thesis that what other generations had believed to be firm was in fact moving, slipping, sliding ("das Gleitende"). In Ein Brief ( $A$ Letter, 1902), a fictitious letter written by Lord Chandos in 1603 and addressed to Francis Bacon, he expressed a deep dissatisfaction with language. Later he abandoned lyric poetry for prose fiction and drama. Among his highly stylized short stories Der goldene Apfel (The Golden Apple, 1897) and Dämmerung und nächtliches Gewitter (Twilight and Night Storm, 1911-1913) are deliberately unfinished or open-ended. His early one-act verse play Der Tor und der Tod (The Fool and Death, 1893) relies on the tradition of moralities. Claudio is visited by death, who, playing his violin, brings three visitors from the other world to the hero's study: his mother, his lover, and his friend. This work paved the way for the poet's revival of Everyman. He reworked Thomas Otway's blank-verse tragedy Venice Preserved, or a Plot Discovered (1682) and Calderón's La vida es sueno (1635). His adaptation of the Greek drama Elektra (1904), suggesting that the tragedy happens within the heroine's mind, inspired Richard Strauss to compose his most chromatic opera, produced in 1909. Their collaboration continued with other libretti for the operas Der Rosenkavalier (1911), Ariadne auf Naxos (Ariadne on the Island of Naxos, 1912), Die ägyptische Helene (1928), and Arabella (193). In Der Rosenkavalier he expressed a nostalgia for the period of 
Maria Theresa, whereas in the semiseria Ariadne he relied on the tradition of a play within the play. It is probably no great exaggeration to suggest that Hofmannsthal's later eclecticism could be linked to his inability to accept the disappearance of the Habsburg Monarchy. One could go one step further and argue that the relative failure of Die Frau ohne Schatten (The Woman without a Shadow, 1919), a highly ambitious opera by Strauss, may at least partly be due to the artificial fantasy play based on the longer prose narrative juxtaposing a fairy-tale emperor and empress with the earthly characters of a dyer and his wife.

The setting for Der Tor und der Tod is a villa in the 1820s. Hofmannstal's nostalgia for the Biedermeier is contemporaneous with the art historian Riegl's rehabilitation of Biedermeier culture, Klimt's panel Schubert at the Piano (1899) or the music-salon of the Ringstraße Maecenas Nikolaus Dumba, as well as Mahler's evocations of early nineteenth-century music and his numerous settings to music of pieces from the collection Des Knaben Wunderhorn (1805-1808) made by Achim von Arnim and Clemens von Brentano.

\author{
Auf der Straß stand ein Lindenbaum, \\ da hab' ich zum ersten Mal im Schlaf geruht! \\ (Upon the road there stood a linden tree, \\ there for the first time I slept in peace!)
}

These words from the final song of the cycle Lieder eines fahrenden Gesellen (Songs of a Wayfarer, 1884) refer back to the fifth song of Schubert's Winterreise (1827). Rewriting continued to be cultivated by the younger generation, reaffirming the unity of innovation and conservatism characterizing the culture of the Monarchy. Kokoschka's playlet Mörder, Hoffnung der Frauen (Murder, Hope of Women), staged in 1909 and published in the Expressionist periodical Der Sturn (The Storm) in 1910, for instance, is based on Heinrich von Kleist's Penthesilea (1808).

\title{
7. In Lieu of a Conclusion
}

The wide range of cultural products, from the annual performances of Jedermann at the Salzburger Festspiele to novels, play, and poems recalling the past, testifies to the significance of the cultural legacy of the Dual Monarchy. Instead of drawing a conclusion, let it suffice to mention two symptomatic facts. On November 3, 1914 a Medical Corps lieutenant of the Austro-Hungarian army died in a hospital in Cracow at the age of twenty-six. Deranged by what he had experienced as a dispensing chemist in the battle of Grodek, he had taken an overdose of drugs. Today this Salzburg-born poet Georg Trakl (1887-1914) is read as one of the greatest lyric poets of the twentieth century. His three hundred poems appeared in Ludwig von Ficker's periodical Der Brenner in 1914-1915 and in two 
collections: Gedichte (Poems, 1913) and Sebastian im Traum (Sebastian in Dream, 1914). In his Expressionist poetry the invisible is made visible, the physical world is subordinated to the spiritual, the soul is called a stranger on the earth: "Es ist die Seele ein Fremdes auf Erden", as the poem "Frühling der Seele" "The Spring of the Soul") affirms, and pain is an existential gift of everything that exists - "Der Schmerz ist die Gunst des Wesenhaften alles Wesenden", as his interpreter says (Heidegger, 1985, 60). His language of extreme concentration is as exceptional in literature as the texture of Webern's music. The last of Webern's cycle of orchestral songs, Vier Lieder (op. 13, completed after an interruption occasioned by military duties in 1918), and his Sechs Lieder (op. 14, composed between 1917 and 1921) for voice with clarinet, bass clarinet, violin, and cello, are based on poems by Trakl.

In 1945 this composer was staying in the small house of his brother-in-law near Salzburg. On September 15 he had supper with his family. Around 9 o'clock he stepped out of the house because he did not want to disturb his grandchild with his smoking. An American soldier shot him. Later at the trial this soldier tried to argue that he acted in self-defence. His statement was dismissed as untrue. "Do you know what kind of myth that's going to make in a thousand years?" asks a character in one of the great American novels of the second half of the twentieth century, and then he gives the following answer: "The young barbarians coming in to murder the Last European, standing at the far end of what'd been going on since Bach" (Pynchon 1975, 440).

These two incidents might be regarded as an epilogue to the history of the culture of the country once known as the Austro-Hungarian Monarchy.

\section{References}

Babits, Mihály (1978) Esszék, tanulmányok. Ed. György Belia. Budapest: Szépirodalmi.

Babits, Mihály (2001) Timár Virgil fia. Ed. Lajos Sipos. Budapest: Magyar Könyvklub.

Boulez, Pierre (1966) Relevés d'apprenti. Textes réunis et présentés par Paul Thénevin. Paris: Seuil. Boulez, Pierre (1986) Orientations: Collected Writings. Ed. Jean-Jacques Nattiez. Translated by Martin Cooper. Cambridge, MA: Harvard University Press.

Forgács, Éva (1994) “Avant-Garde and Conservatism in the Budapest Art World: 1910-1932", in Bender, Thomas and Carl E. Schorske (eds.) Budapest and New York: Studies in Metropolitan Transformation 1870-1930. New York: Russell Sage Foundation, 309-331.

Fülep, Lajos (1974) A müvészet forradalmától a nagy forradalomig: Cikkek, tanulmányok. Ed. Árpád Tímár. Budapest: Magvető.

Granger, Gilles-Gaston (1969) Ludwig Wittgenstein. Paris: Seghers.

Gray, Ronald (1973) Franz Kafka. Cambridge: Cambridge University Press.

Hanák, Péter (1994) "The Cultural Role of the Vienna-Budapest Operetta", in Bender, Thomas and Carl E. Schorske (eds.) Budapest and New York: Studies in Metropolitan Transformation 1870-1930. New York: Russell Sage Foundation, 209-223. 
Heidegger, Martin (1985) Unterwegs zur Sprache. Frankfurt am Main: Vittorio Klostermann. Janik, Allen and Stephen Toulmin (1973) Wittgenstein's Vienna. New York: Simon and Schuster. Jeszenszky, Géza (1986) Az elvesztett presztizs: Magyarország megitélésének megváltozása Nagy-Britanniában (1894-1918). Budapest: Magvető.

Kokoschka, Oscar (1992) Letters 1905-1976. London: Thames and Hudson.

Kolakowski, Leszek (1972) Positivist Philosophy from Hume to the Vienna Circle. Translated by Norbert Gutervan and revised by the author. Harmondsworth, Middlesex: Penguin Books.

Kolar, Mira (2005) "The Activities of Vice-Roy Pavao Rauch in Croatia". Review of Croatian History, 1.1: 133-157.

Kosztolányi, Dezső (1975) Ércnél maradandóbb. Ed. Pál Réz. Budapest: Szépirodalmi.

Kosztolányi, Dezső (1977) Egy ég alatt. Ed. Pál Réz. Budapest: Szépirodalmi.

Kosztolányi Dezső (2002) Nyelvés lélek. Ed. Pál Réz. Budapest: Osiris.

Krišto, Jure (2005) "Croatian Political Turmoils in the Dusk of the Austro-Hungarian Monarchy", Review of Croatian History, 1.1: 73-94.

Lechner, Ödön (1906) "Magyar formanyelv nem volt, hanem lesz”. Müvészet, 5.1: 1-18.

Levy, Richard S. (1991) Antisemitism in the Modern World: An Anthology of Texts. Lexington, MA - Toronto: D. C. Heath and Co.

L. Nagy, Zsuzsa (1994) "Transformations in the City Politics of Budapest: 1873 1941", in Bender, Thomas and Carl E. Schorske (eds.) Budapest and New York: Studies in Metropolitan Transformation 1870-1930. New York: Russell Sage Foundation, 35-54.

Lukacs, John (1988) Budapest 1900: A Historical Portrait of a City and Its Culture. New York: Weidenfeld and Nicolson.

Madsen, S. Tschudi (1976) Art Nouveau. Translated by R. I. Chrsitopherson. New York - Toronto: McGraw Hill Book Co.

Mason, John W. (1985) The Dissolution of the Austro-Hungarian Empire 1867-1918. London: Longman.

Mikszáth, Kálmán (1887) Club és folyosó: Politikai ötletek és rajzok. Budapest: Révai.

Musil, Robert (1970) Der Mann ohne Eigenschaften: Roman. Ed. Adolf Frisé, Reinbek bei Hamburg: Rowohlt.

Neumer, Katalin (2004) "Wittgenstein und die 'Philosophen des Lebens' oder War Wittgenstein ein 'österreichischer' Philosoph? Zu Rodolf Hallers Konzeption einer eigensteidigen Österreichischen Philosophie", in Katalin Neumer (ed.) Traditionen Wittgensteins. Frankfurt am Main: Peter Lang, 103-132.

Popper, Karl (1982) Unended Quest: An Intellectual Autobiography. Sixth Impression, with extended bibliography. Glasgow: Fontana/Collins.

Pynchon, Thomas (1975) Gravity's Rainbow. London: Picador.

Rilke, Rainer Maria (1997) Die Aufzeichnungen des Malte Laurids Brigge. Ed. Manfred Engel. Stuttgart: Reclam.

Romsics, Ignác (2001) A trianoni békeszerzödés. Budapest: Osiris.

Schoenberg, Arnold (1984) Style and Idea: Selected Writings. Berkeley - Los Angeles: University of California Press.

Schorske, Carl E. (1980) Fin-de-siècle Vienna: Politics and Culture. New York: Alfred A. Knopf.

Seton-Watson, R. W. (1912) Absolutism in Croatia. London: Constable and Co.

Szegedy-Maszák, Mihály (2007a) Szó, kép, zene: A müvészetek összehasonlító vizsgálata. Pozsony: Kalligram.

Szegedy-Maszák, Mihály (2007b) “Életmüvek kölcsönhatása”, in Szegedy-Maszák, Mihály (ed.) A magyar irodalom történetei. Budapest: Gondolat, 2: 738-753.

Vikárius, László (1999) Modell és inspiráció Bartók zenei gondolkodásában. Pécs: Jelenkor. 
Vogel, Jaroslav (1962) Leoš Janáček: His Life and Works. Translated by Geraldine Thomsen-Muchová. London: Paul Hamlyn.

Wittgenstein, Ludwig (1974) Philosophical Investigations. Translated by G. E. M. Anscombe. Oxford: Basil Blackwell.

Wittgenstein, Ludwig (1980) Culture and Value. Ed. G. H. von Wright in collaboration with Heikki Nyman. Chicago: The University of Chicago Press.

Wittgenstein, Ludwig (1985) Tractatus Logico-Philosophicus. London: Routledge and Kegan Paul.

Zweig, Stefan (1981) Die Welt von Gestern: Erinnerungen eines Europäers. Berlin - Weimar: Aufbau. 